\title{
Phytochemical Screening and Anti-Inflammatory Activities of Methanolic Leaf Extract of Bauhinia monandra in Animal Models
}

\author{
Augustine Nkemakolam Okorie ${ }^{1, a}$, Kelechi Martins Nworie ${ }^{2, b *}$ \\ ${ }^{1}$ Department of Pharmacology and Toxicology, University of Nigeria, Nsukka, Nigeria. \\ ${ }^{2}$ Pharmaceutical Outcomes Research Group, Faculty of Pharmacy, University of Nigeria, Nsukka, \\ Nigeria. \\ aemail: nkemakolam.okorie@unn.edu.ng, \\ ${ }^{b, *}$ Corresponding email: nworiekelechimartins@gmail.com
}

Keywords: B. monandra, anti-inflammatory, edema, phytochemical studies

\begin{abstract}
The leaves of Bauhinia monandra prepared as poultices are used in many Brazilian tribes and some Nigerian communities to relieve swelling and pains, arthritis, diabetes among other ailments. These folkloric claimed benefits inspired this study in which topical and systemic antiinflammatory activities of a methanol extract of $B$. monandra leaves (MEBmL) was assessed in rodents. The anti-inflammatory activities of $B$. monandra were determined by egg albumin-induced (systemic) paw edema in rats, and xylene-induced (topical) ear edema in mice. Treatment of rats with MEBmL at different concentration $(200$ and $400 \mathrm{mg} / \mathrm{kg})$ led to significant $(p<0.05)$ reduction (31.0\% and $28.0 \%$ respectively) of the egg albumin-induced paw edema. Topical application of mice ear with MEBmL $(50,100 \mathrm{mg} / \mathrm{kg})$ also significantly $(p<0.05)$ reduced $(39.50 \%$ and $41.87 \%$ respectively) xylene-induced ear edema. Based on the findings of the study, B. monandra has a promising therapeutic potential with its anti-inflammatory activities as associated with folkloric use of the plant.
\end{abstract}

\section{Introduction}

Plant metabolites are important source of natural bioactive molecules with a vast range of pharmacological activities which are known to exert pharmacological actions in the body, thereby enhancing curative and preventive properties of different diseases [1]. Recently, the use of medicinal plants has gained global attention as most of the world's population seeks medicinal plants as therapeutic source, including compound prototypes from laboratory synthesis.

Bauhinia monandra also known as cow's foot, orchid tree, Napoleon plume, Flamboyant, St Thomas tree is a species of leguminous trees that belong to the Caesalpinaceae family [2]. It is an evergreen shrub or tree with a rounded crown, which can grow up to 3-15 meters tall. B. monandra is often planted for its beautiful flowers and ornamental foliage. It is cultivated as a garden and street tree in the tropical regions of Australia, America, Asia and West Indies [3]. B. monandra seeds are useful source of vitamin A, and contain high amounts linoleic and fatty acid and low amounts of mystiric acids [3].

Inflammation is a complex biological response of vascular tissues to invasion by an infectious agent, antigen challenge, physical, chemical or traumatic damage, and is a protective response involving immune cells [4], blood vessel, and molecular mediators. It is considered a mechanism of innate immunity. Although inflammation is physiological defense mechanism, too little inflammation may lead to continuous tissue damage by harmful stimulus and compromise the survival of the organism [4]. Furthermore, chronic inflammation reactions can induce, maintain or aggravate a host of diseases such as hay fever, periodontitis, atherosclerosis, rheumatoid arthritis, and some cancer [5]. Therefore, inflammation is closely regulated by the body. The non-steroidal anti-inflammatory drugs (NSAIDS) are usually used for the treatment of inflammatory conditions including osteoarthritis, rheumatoid arthritis, and musculoskeletal disorders [6]. They are generally used for symptomatic relief. However, with the vast use of NSAIDS, adverse effects have become increasingly common including gastrointestinal disorders, kidney disease, and a range of 
cardiovascular events [7-8]. Therefore, new anti-inflammatory drugs without these adverse effects are needed as alternatives to NSAIDS. The use of medicinal herbs is rapidly gaining acceptance due to their effectiveness, availability, and probably low toxicity, and the progressive inefficiency of modern medicines [9].

Research evidence has shown that B. monandra possesses antidiabetic properties against experimentally induced diabetes in rats [10]. Its antidiabetic activity has been linked to the presence of antioxidant compounds [9] which had also been studied [9]. Native Bauhinia species (Leguminosae) have been widely employed in folk medicine for the treatment of diabetes. In Brazil, leaves of the species B. purpurea Linn., B. forficata Link., and B. monandra Kurz. are commonly used as teas for treatment of diabetes [11].Due to the elevated costs of commercial diabetes medication, Brazilian folks often prefer the use of infusions of Bauhinia sp as alternative for treating diabetes, and other ailments [11-13].Report have also shown a wide range of pharmacological activities from different species of this genus [11-12], but very few have reported the anti-inflammatory activity of $B$. monandra. Some bioactive compounds that have been isolated from this genus include flavonoids, tannins, lactones, steroids, terpenoids, and glycolipids [11-13]. Since there are scarce experimental studies about its anti-inflammatory activity, the scope of this study was to evaluate whether the methanolic extracts obtained from dried B. monandra leaves are able to promote anti-inflammation in animal models, and contributing phytoconstituents of this common medicinal plant in folk medicine.

\section{Materials and Methods}

\section{Chemicals}

All chemicals used in this study were of analytical grade. They were products of Sigma Aldrich, Germany. All laboratory reagents and distilled water were freshly prepared.

\section{Collection and extraction of plant material}

Fresh aerial leaves of B. monandra were collected in February 2018 from the Botanical garden of the Department of Plant Science and Biotechnology, University of Nigeria, Nsukka $\left(6^{\circ} 51^{\prime} 24^{\prime \prime} \mathrm{N}, 7^{\circ} 23^{\prime} 45^{\prime \prime} \mathrm{E}\right)$ where it was appropriately identified and authenticated by Dr. Nweze, a taxonomist. A voucher specimen was deposited in the herbarium unit of Department of Plant Science and Biotechnology, University of Nigeria, Nsukka with specimen voucher number, UNH 1559. The leaves obtained were washed properly to remove dust and dirt, air-dried for 3 weeks and milled with a laboratory-scale mechanical grinder (Elapaq GX160, China). The pulverized plant leaves $(500 \mathrm{~g})$ was cold macerated in $2 \mathrm{~L}$ of methanol for $72 \mathrm{~h}$ with agitation at intervals. The extract solution was then filtered through Whatman No. 1 filter paper. The filtrate obtained was concentrated in a rotary evaporator (IKA RV3, Germnay) under reduced pressure at $45^{\circ} \mathrm{C}$ for $3 \mathrm{~h}$, and the resultant methanolic extract of $B$. monandra (MEBmL) leaves was stored at $4^{\circ} \mathrm{C}$ in a refrigerator for subsequent use.

\section{Experimental animals}

Swiss albino mice (25-32g) and Wistar rats (125-200 g) of both sexes were obtained from the animal house of the Department of Pharmacology and Toxicology, University of Nigeria, Nsukka. They were housed in metal steel cages in a well-ventilated animal house under 12:12 hour light dark cycle. The animals were provided with normal pellet diet and water ad libitum, and allowed to acclimatize to environmental conditions for seven days prior to commencement of the experiments. The research protocols were in accordance with the ethical rules and recommendation of the University of Nigeria committee on the use and handling of laboratory animals. These principles are also in accordance to the National Research Council Guide for Care and Use of Laboratory Animals [14]. 


\section{Preliminary phytochemical screening}

Phytochemical analysis was carried out on the methanolic leaf extract of $B$. monandra using standard procedures [15-16].

\section{Acute toxicity study}

The acute toxicity study of leaf methanolic extract of $B$. monandra was evaluated according to the procedures outlined by the Organization for Economic Co-operation and Development (OECD) [17]. Eighteen Swiss albino mice of both sex grouped into three groups (six mice per group) were used for the study. Following the fasting period, a single dose of methanolic extract of $B$. monandra $(100,500,1000$ and $2000 \mathrm{mg} / \mathrm{kg})$ were administered orally to in the treatment groups. Another six mice were administered distilled water as control group. Food was allotted to the mice exactly one hour after treatments. The mice were closely and carefully observed within the first $6 \mathrm{~h}$ for any indication of toxicity effect, and daily for a duration of 14 days. Animals were visually observed daily for mortality, behavioral pattern, changes in physical appearance, injury, pain and signs of illness during the duration of study.

\section{Evaluation of anti-inflammatory activity}

Two models were used for assay of anti-inflammatory potential of methanolic extract of $B$. monandra. Thirty adult Wistar rats or adult Swiss albino mice of either sex were used. They animals were randomly divided into five groups of six animals per group. They were fasted for $18 \mathrm{~h}$ prior to the experiment.

\section{Egg albumin-induced paw edema}

The rat paw method as described by Akah et al. [18] was used for the test. The rats were divided into five groups of six per group. Group I, II, III, and IV were administered methanolic extract of $B$. monandra $(100,200,400 \mathrm{mg} / \mathrm{kg}$, i.p.) and indomethacin $(10 \mathrm{mg} / \mathrm{kg}$, i.p.) suspended in distilled water respectively. Group $V$ received distilled water only $(1 \mathrm{~mL} / \mathrm{kg}$, i.p. $)$ as control group. Approximately one hour after treatment, inflammation of the hind paw was induced by injecting 0.1 $\mathrm{mL}$ of undiluted fresh egg albumin into the subplanter surface of the right hind paw of rats. The right hind paw volumes of the rats were determined on the principle of volume displacement using the Digital Plethysmometer. Paw volumes were measured at $0.5,1,2,3,4$ and 5 hours after the injection of egg albumin. The mean edema at every time interval was determined in terms of difference in volume displacement at time $t$, and zero time $\left(V_{t}-V_{0}\right)$. Percent inhibition of edema was calculated using the formula:

$$
\% \text { inhibition }=\left[\left(\mathrm{V}_{\mathrm{c}}-\mathrm{V}_{\mathrm{t}}\right) \div \mathrm{V}_{\mathrm{c}}\right] \times 100,
$$

where $V_{c}=$ the volume of edema of the control (distilled water treated) group at time $t, V_{t}=$ the volume of edema at corresponding time of the treated rats.

\section{Xylene-induced ear edema}

The acute topical inflammation in mice ear was evaluated by a modification of the method described by Tjolsen et al. was used [19]. The mice were divided into five groups of six per group. Group I, II, III and IV received 2 drops of methanolic extract of $B$. monandra $(25,50,100 \mathrm{mg} / \mathrm{kg}$ ) and indomethacin $(10 \mathrm{mg} / \mathrm{kg})$ applied on the anterior surface of the right ear. Group $\mathrm{V}$ received distilled water ( 2 drops) as control group. Topical inflammation was immediately induced on the posterior surface of the same right ear by application of $0.05 \mathrm{~mL}$ of xylene. Fifteen minutes after induction, mice were killed by overdose chloroform anesthesia. Circular sections of both right (treated) and left (untreated) ears were punched out using a $6 \mathrm{~mm}$ cork borer and weighed appropriately. The mean ear edema was determined in terms of weight difference between the earplugs. Percent inhibition of edema was calculated using the formula:

$$
\% \text { inhibition }=100 \times[1-(\mathrm{Rt}-\mathrm{Lt}) \div(\mathrm{Rc}-\mathrm{Lc}]
$$


where $\mathrm{Rt}=$ mean weight of right earplug of treated animals, $\mathrm{Lt}=$ mean weight of left earplug of treated animals, $\mathrm{Rc}=$ mean weight of right earplug of control animals, $\mathrm{Lc}=$ mean weight of left earplug of control animals.

\section{Statistical analysis}

This was done using SPSS version 16.0 (SPSS Inc. Chicago, IL. USA). All values are expressed as mean \pm SEM. Data were analyzed student t-test and one-way ANOVA. Difference between means were considered statistically significant at $\mathrm{P}<0.05$.

\section{Results}

\section{Preliminary phytochemical screening}

The phytochemical constituents of methanolic extract of B. monandra are shown in Table 1. The extract contains abundance of important phytochemicals of active medicinal constituents. Phytochemicals found present include reducing sugar, proteins, carbohydrates, flavonoids, saponins, resins, steroids, oils, terpenoids, alkaloids, tannins, and cardiac glycosides.

Table 1. Preliminary phytochemical screening of methanolic extract of $B$. monandra leaves

\begin{tabular}{|l|l|}
\hline Phytoconstituents & Inference \\
\hline Reducing sugar & + \\
\hline Proteins & +++ \\
\hline Carbohydrate & + \\
\hline Flavonoid & ++ \\
\hline Saponin & ++ \\
\hline Acidic compounds & + \\
\hline Resin & + \\
\hline Steroids & ++ \\
\hline Oils & ++ \\
\hline Terpenoid & ++ \\
\hline Alkaloid & ++ \\
\hline Tannins & +++ \\
\hline Cardiac glycosides & + \\
\hline
\end{tabular}

+: present; ++: moderately present; +++: highly present

\section{Acute Toxicity study (LD $\left.\mathbf{5 0}_{\mathbf{5 0}}\right)$}

Result of the acute toxicity study showed that no early or late mortality or any significant change in behavioral and physical activities was observed in mice administered up to $1 \mathrm{~g} / \mathrm{kg}$ of methanolic extract of $B$. monandra leaves. No animal showed any significant alteration in behavioral, physiological and physical activities. The indication is that the oral administration of $B$. monandra extract did not produce any visible toxic effect.

Effect of methanolic extract of $B$. monandra leaves (MEBmL) on egg albumin-induced paw edema in rats

Pre-treatment of rats with MEBmL (200 and $400 \mathrm{mg} / \mathrm{kg})$ caused significant $(p<0.05)$ reduction of egg albumin-induced inflammation and a rapid resolution of paw edema over a 5-h period, except at a dose of $100 \mathrm{mg} / \mathrm{kg}$ (Fig. 1). Administration of MEBmL showed a significant 
$(p<0.05)$ anti-inflammatory activity $(\mathrm{MEBmL} 200$ and $400 \mathrm{mg} / \mathrm{kg})$ reducing the egg paw edema in a non dose-dependent manner (Table 2). Two hours after egg albumin injection, a significant $(p<0.05)$ reduction $(25 \%$ and $17 \%)$ in paw edema was observed in rats treated with MEBmL 200 and $400 \mathrm{mg} / \mathrm{kg}$ respectively. After $5 \mathrm{~h}$, a significant $(p<0.05)$ paw edema reduction was observed with MEBmL at these concentrations. The rats treated with Indomethacin $(10 \mathrm{mg} / \mathrm{kg})$ showed the best anti-inflammatory activity $(33 \%)$ after $5 \mathrm{~h}$ (Figю 1 ). The edema inhibition demonstrated by MEBM was similar to that obtained in positive control (Indomethacin, $10 \mathrm{mg} / \mathrm{kg}$ ).

Table 2. Effect of methanolic extract of B. monandra leaves on egg albumin induced paw edema in rats

\begin{tabular}{|c|c|c|c|c|c|c|}
\hline \multirow{2}{*}{$\begin{array}{c}\text { Treatment } \\
\text { Groups }\end{array}$} & \multicolumn{6}{|c|}{ Mean paw edema $(\mathrm{mL})$ and inhibition of edema $(\%)$} \\
\hline & $0.5 \mathrm{~h}$ & $1.0 \mathrm{~h}$ & $2.0 \mathrm{~h}$ & $3.0 \mathrm{~h}$ & $4.0 \mathrm{~h}$ & $5.0 \mathrm{~h}$ \\
\hline $\begin{array}{c}\text { Group I } \\
\text { (100 mg/kg of } \\
\text { MEBmL) }\end{array}$ & $\begin{array}{c}0.60 \pm 0.01 * * \\
(9.00)\end{array}$ & $\begin{array}{c}0.65 \pm 0.03^{* * *} \\
\quad(10.00)\end{array}$ & $\begin{array}{l}0.65 \pm 0.03 \\
\quad(8.00)\end{array}$ & $\begin{array}{c}0.55 \pm 0.07 \\
\quad(5.00)\end{array}$ & $\begin{array}{c}0.32 \pm 0.04 \\
(11.00)\end{array}$ & $\begin{array}{c}0.26 \pm 0.03 \\
(14.00)\end{array}$ \\
\hline $\begin{array}{c}\text { Group II } \\
(200 \mathrm{mg} / \mathrm{kg} \text { of } \\
\mathrm{MEBmL})\end{array}$ & $\begin{array}{c}0.68 \pm 0.06 \\
\quad(5.00)\end{array}$ & $\begin{array}{c}0.58 \pm 0.00 * * * \\
(17.00)\end{array}$ & $\begin{array}{c}0.48 \pm 0.00 * \\
(25.00)\end{array}$ & $\begin{array}{c}0.28 \pm 0.01 * * \\
\quad(32.00)\end{array}$ & $\begin{array}{c}0.11 \pm 0.03 * \\
(32.00)\end{array}$ & $\begin{array}{c}0.09 \pm 0.01 * * \\
\quad(31.00)\end{array}$ \\
\hline $\begin{array}{c}\text { Group III } \\
(400 \mathrm{mg} / \mathrm{kg} \text { of } \\
\mathrm{MEBmL})\end{array}$ & $\begin{array}{c}0.62 \pm 0.01 * * \\
(7.00)\end{array}$ & $\begin{array}{c}0.63 \pm 0.03 * * \\
\quad(12.00)\end{array}$ & $\begin{array}{c}0.56 \pm 0.07 \\
(17.00)\end{array}$ & $\begin{array}{c}0.32 \pm 0.04^{*} \\
\quad(28.00)\end{array}$ & $\begin{array}{c}0.08 \pm 0.01 * * \\
\quad(35.00)\end{array}$ & $\begin{array}{l}0.12 \pm 0.04^{*} \\
\quad(28.00)\end{array}$ \\
\hline $\begin{array}{c}\text { Group IV } \\
\text { (10 mg/kg of } \\
\text { Indomethacin) }\end{array}$ & $\begin{array}{c}0.60 \pm 0.01 * * \\
(9.00)\end{array}$ & $\begin{array}{c}0.46 \pm 0.01 * * * \\
\quad(32.00)\end{array}$ & $\begin{array}{c}0.30 \pm 0.00^{* *} \\
\quad(43.00)\end{array}$ & $\begin{array}{c}0.09 \pm 0.00^{* * *} \\
\quad(51.00)\end{array}$ & $\begin{array}{c}0.07 \pm 0.03 * * \\
\quad(36.00)\end{array}$ & $\begin{array}{c}0.07 \pm 0.03 * * \\
\quad(33.00)\end{array}$ \\
\hline $\begin{array}{l}\text { Group V } \\
\text { (Normal } \\
\text { Control) }\end{array}$ & $0.69 \pm 0.01$ & $0.75 \pm 0.01$ & $0.73 \pm 0.09$ & $0.60 \pm 0.06$ & $0.43 \pm 0.07$ & $0.40 \pm 0.06$ \\
\hline
\end{tabular}

$*^{* *} p<0.001 ; * * p<0.01 ; * p<0.05$, when all groups compared to control group. All values are represented as mean $\pm \mathrm{SEM}(\mathrm{n}=5) . \mathrm{MEBM}=$ Methanolic extract of $B$. monandra. All values in parenthesis ( ) are percentage inhibition of edema calculated relative to control.

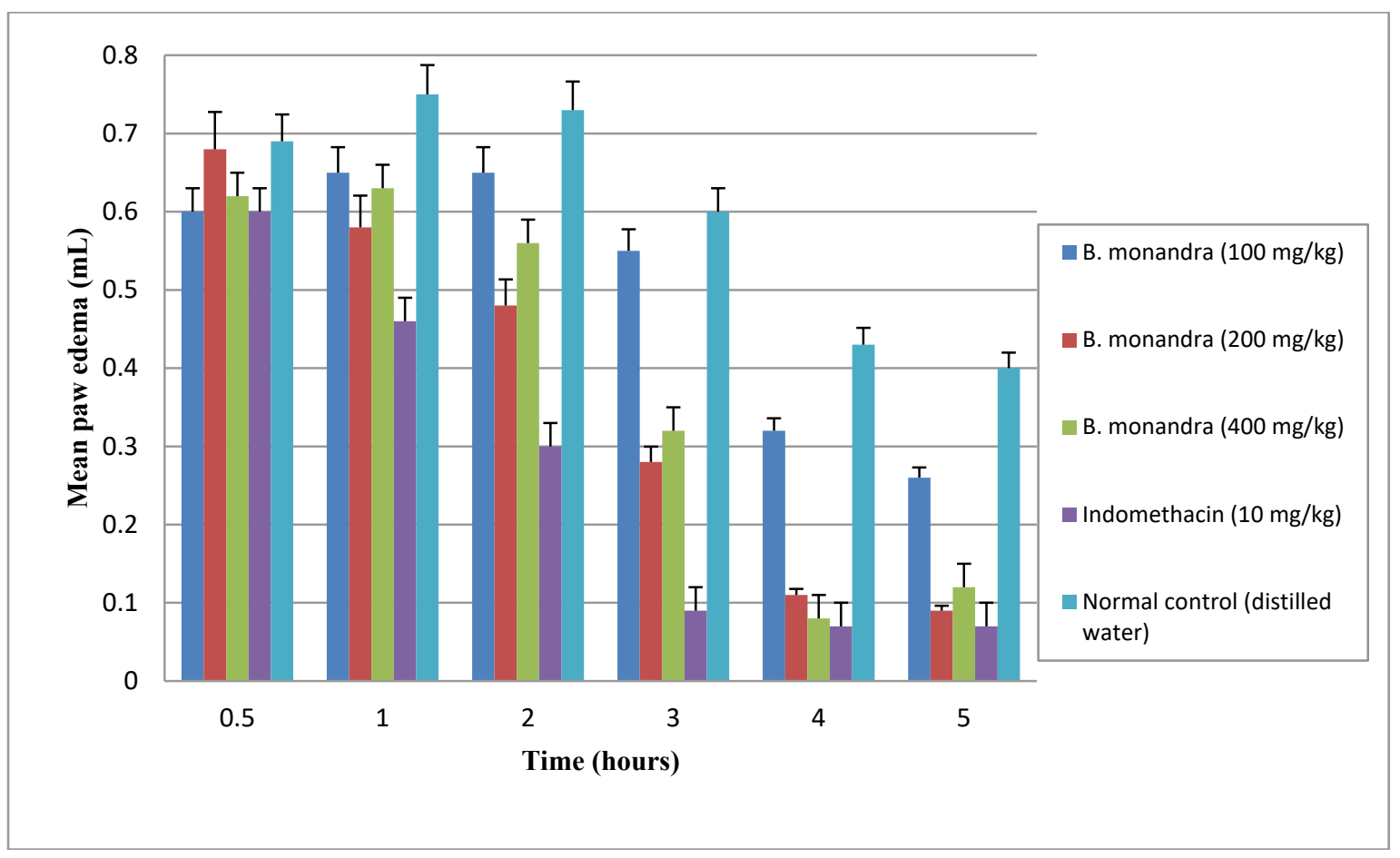

Figure 1. Effect of methanolic extract of $B$. monandra leaves on egg albumin-induced paw edema in rats 


\section{Effect of methanolic extract of $B$. monandra leaves (MEBmL) on xylene-induced topical ear edema in mice}

The administration of MEBmL in different concentrations $(25,50$ and $100 \mathrm{mg} / \mathrm{kg})$ showed a significant reduction (37.19, 39.50 and 40.87 respectively) in the topical ear edema induced by xylene application, compared with the normal control group (Table 3). The group treated with indomethacin $(5 \mathrm{mg} / \mathrm{kg})$ showed significant recduction $(55.83 \%)$ of ear edema (Fig. 2). The antiinflammatory activity produced by $\mathrm{MEBmL}(100 \mathrm{mg} / \mathrm{kg})$ is comparable to that produced by the positive control (Indomethacin, $5 \mathrm{mg} / \mathrm{kg}$ ).

Table 3. Effect of methanolic extract of B. monandra (MEBM) on xylene-induced topical ear edema in mice

\begin{tabular}{|c|c|c|}
\hline Treatment Groups & Mean ear edema (mg) & Inhibition of edema (\%) \\
\hline $\begin{array}{c}\text { Group I } \\
(25 \mathrm{mg} / \mathrm{kg} \text { of MEBmL) }\end{array}$ & $9.00 \pm 2.65$ & 37.19 \\
\hline $\begin{array}{c}\text { Group II } \\
(50 \mathrm{mg} / \mathrm{kg} \text { of MEBmL) }\end{array}$ & $8.67 \pm 1.45^{*}$ & 39.50 \\
\hline $\begin{array}{c}\text { Group III } \\
(100 \mathrm{mg} / \mathrm{kg} \text { of MEBmL) }\end{array}$ & $8.33 \pm 1.45^{*}$ & 41.87 \\
\hline $\begin{array}{c}\text { Group IV } \\
(5 \mathrm{mg} / \mathrm{kg} \text { of Indomethacin) }\end{array}$ & $6.33 \pm 1.20^{* *}$ & 55.83 \\
\hline $\begin{array}{c}\text { Group V } \\
(\text { Normal control })\end{array}$ & $14.33 \pm 0.88$ & - \\
\hline
\end{tabular}

$*^{*} p<0.01 ; * p<0.05$, when all groups compared to control group. All values are represented as mean \pm SEM $(n=5)$. MEBM=Methanolic extract of $B$. monandra. All values of percentage inhibition of edema calculated relative to control

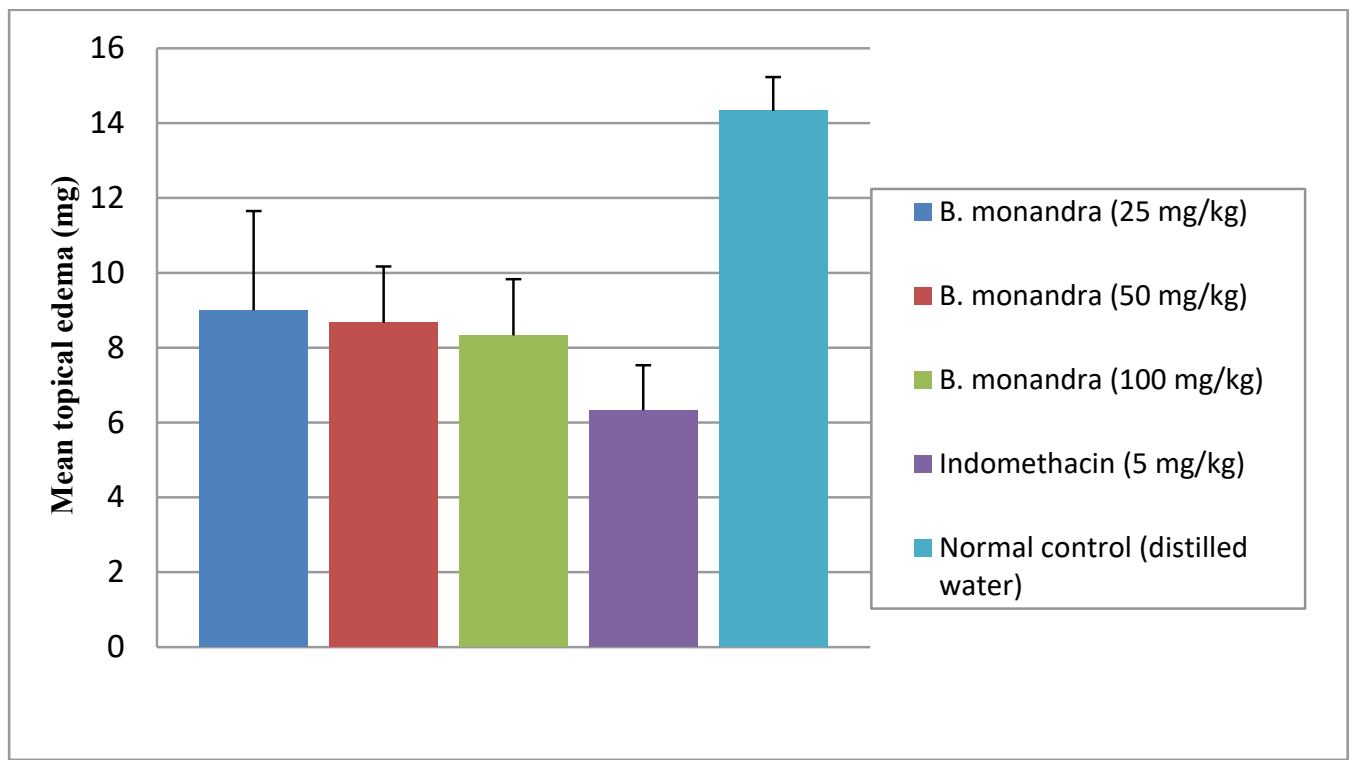

Figure 2. Effect of methanolic extract of B. monandra leaves (MEBmL) fifteen minutes after xylene-induced topical ear edema in mice

\section{Discussion}

Inflammation is basically a body protective mechanism which is aimed at ridding the body of both the initial cause of cell injury (e.g. microbes, toxins) and the sequelae of such injury (e.g. necrotic cells and tissues) [20]. Counter-regulatory mechanisms which are also known as innate anti-inflammatory mechanisms serve to control inflammatory responses and prevent them from causing unwanted damage to the host. These may include termination, break down and dissipation of secreted mediators when the offending agent is eliminated. Failure of these innate anti- 
inflammatory mechanisms results to inflammatory diseases such as rheumatism and arthritis [20]. The discovery of acetylsalicylic acid (aspirin) from the bark of the Willow plant (Salixalba) more than a century ago, have given lead to other non-steroidal and steroidal anti-inflammatory drugs. However, continuous use and administration of these drugs is associated with some serious side effects including renal problems, gastrointestinal irritation and ulceration [21]. Therefore, research on inflammation is gaining focus on global scientific study because of the unmet need of discovering potent anti-inflammatory molecules that are devoid of these side effects as alternatives. This has prompted scientific investigation of medicinal plants used in traditional and folk medicine for treating fever, pains, and rheumatoid arthritis [22].

The present study investigated the anti-inflammatory activity of the methanolic extract of Bauhinia monandra (MEBmL) on experimentally induced edema in rodents. The leaves of $B$. monandra are used by the Amofu people in Nigeria to relieve swellings and treat arthritic joints. The flowers and buds of plants of this genus are commonly used to treat dysentery, sore throat, skin diseases, or remedy for dysentery [23-25]. These folkloric claims prompted the present study in which anti-inflammatory activities of $B$. monandra extract were evaluated in rodents and was found effective in reducing inflammation in both topical and systemic inflammation.

The result shows that MEBmL significantly inhibited acute inflammation on egg albumininduced edema in rats pre-treated with MEBmL, both at the early and later phase of edema. The edema inhibition demonstrated by MEBmL was comparable to that demonstrated by the standard drug, indomethacin. This result supports a previous study which evaluated the anti-inflammatory and antinociceptive activities of $B$. monandra leaf lecithin [26]. The study revealed that lecithin isolated from the leaf of $B$. monandra (given at 15,30 and $60 \mathrm{mg} / \mathrm{kg}$ ) yielded a significant dosedependent inflammatory inhibition on carrageenan-induced paw edema. Preliminary phytochemical screening of MEBmL revealed the presence of alkaloids, tannins, flavonoids, terpenoids, saponin, glycosides, steroids and acidic compounds (Table 1). Although based on the study we were unable to relate these constituents with the anti-inflammatory activities observed, bioactive constituents in plants are responsible for their therapeutic activities [1]. For instance, a study identified lecithin from leaves of B. monandra as the possessing anti-inflammatory and antinociceptive activities [26]. Condensed plant tannins from the seed extract of Marwa (Origanum majorana) were reported by Dhull and coworkers [27] to possess antioxidant properties. Kaur et al. [28] reported that bioactive compounds from Tulsi (Ocimum tenuiflorum) seeds possess antioxidant activities and DNA damage protection.

The vascular and cellular events of inflammation play an important role in the activation of cyclooxygenase (COX-1 and/or COX-2) resulting in release of multiple inflammatory mediators such as histamine, serotonin, bradykinin, prostaglandins [29-30]. The synergistic action of these inflammatory mediators at the local site of inflammatory induction leads to increased vascular permeability and blood flow, hence edema formation [31]. Considering the significant reduction by $B$. monandra in paw edema induced by egg albumin at different time intervals, we can indicate that $B$. monandra may have inhibitory action on the release of inflammatory mediators. Report by Solomon et al. [32] showed that B. tomentosa, a species of Bauhinia inhibited inflammation in vitro. The result in the present study and supported by Solomon et al. indicted. Topical application of $B$. monandra also inhibited acute inflammation induced by xylene in mice. This particular model of xylene-induced ear edema has a good predictive value for screening of anti-inflammatory agents. The phlogistic agent, xylene, when applied topically causes an instant irritation of the mice ear that leads to fluid accumulation/edema - a characteristic of an acute inflammatory response [20]. Therefore, the suppression of this response indicates an anti-inflammatory effect. The methanolic extract of $B$. monandra inhibited inflammation of both egg albumin and xylene-induced edema in a dose related manner. We however could not give specific reason for the dose dependency.

NSAIDs reduce inflammation by inhibiting the activity of COX-1 and/or COX-2 [33]; however, prolonged use of NSAIDs confers some side effects to patients, including gastric lesions and kidney disease [708]. Studies have also reported that plants from Bauhinia genus has antinociceptive and anti-inflammatory [26], anti-oxidant [32], anti-ulcer [34] properties and confers 
nephroprotective effect against cisplatin-induced renal damage [35]. These properties of Bauhinia genus suggest multiple benefits of $B$. monandra, and indicative as a possible anti-inflammatory agent devoid of serious side effects such as gastric lesions, and kidney problems.

Preliminary phytochemical studies showed that the plant is rich in flavonoids, glycosides, terpenoids. Although the present study did not investigate the association of these constituents and anti-inflammatory property, some of these bioactive constituents have been previously reported in previous studies to inhibit the production and release of pro-inflammatory mediators [20]. Plant terpenoids and alkaloids have been reported to possessanti-inflammatory activities and suppress inflammatory responses in rodents [36-38]. Prostaglandins and nitric oxide biosynthesis are involved in inflammation. Nitric oxide synthase and cyclooxygenase (COX-2) are responsible for production of many chemical mediators of inflammation [20]. Flavonoids have been reported to possess potent inhibitory effect on both enzymes [39-40]. Flavonoids modulate inflammatory responses by accelerating the destruction and antagonizing the action of the chemical mediators involved in inflammatory reactions.

\section{Conclusions}

The results from the present study show that $B$. monandra has potent anti-inflammatory properties and this could explain the vast use and benefit of this plant in folk medicine. Furthermore, the study also provided experimental evidence for the effectiveness of $B$. monandra in folk medicine for treating inflammation-associated diseases such as rheumatism. Therefore, $B$. monandra should be further investigated as potential source of anti-inflammatory compounds for pharmacological purposes.

\section{Conflicts of Interest}

The authors declare no conflicts of interest regarding this manuscript. The authors alone are responsible for the content and writing of the manuscript.

\section{References}

[1] R.K. Salazar, S.S. Purewal, Phenolic content, antioxidant potential and DNA damage protection of pearl millet (Pennisetum glaucum) cultivars of North Indian region, Food Meas. 11 (2017) 126-133.

[2] R.W.J. Keay, D.P. Stanfield, C.F.A. Onochie, Trees of Nigeria, Clarendo Press, Oxford, UK, 1989, pp. 74-78.

[3] K.F. Connor, Bauhinia monandra, in: Tropical tree seed manual. Vozzo, J. A. (Eds.), US, USDA Forest Service, Washington DC, 2002, 721, pp. 234-236.

[4] Ferrero-Milliani et al., Chronic inflammation: importance of NOD2 and NALP3 in interleukin-1beta generation, Clin Exp Immunol. 147 (2007) 227-235.

[5] G.C. Machado et al., Non-steroidal anti-inflammatory drugs for spinal pain: a systematic review and meta-analysis, Annals of the Rheumatic Diseases. 76 (2017) 1269-1278.

[6] T.E. Towheed et al., Acetaminophen for osteoarthritis, Cochrane Database Syst. Rev. 1 (2006) CD004257.

[7] A. Rostom et al., Prevention of NSAID-induced gastrointestinal ulcers, Cochrane Database Syst. Rev. 4 (2002) CD002296.

[8] A. Lee et al., Effects of nonsteroidal anti-inflammatory drugs on postoperative renal function in adults with normal renal function, Cochrane Database Syst. Rev. 2 (2007) CD002765.

[9] A.A Anosike, O. Obidoa, L.U.S. Ezeanyika, The anti-inflammatory activity of garden egg (Solanum aethiopicum) on egg albumin-induced edema and granuloma tissue formation in rats, Pac. J. Trop. Med. (2012) 62-66. 
[10] L.M McCune, T. Johns, Antioxidant activity in medicinal plants associated with the symptoms of diabetics mellitus used by the Indegenous people of the North American boreal forest, J. Ethnopharmacol. 82 (2002) 197-205.

[11] K.L. Da Silva et al., Phytochemical and pharmacognostic investigation of Bauhinia forficate Link (Leguminosae), Z. Naturforsch. C. 55 (2000) 478-480.

[12] D.K. Hansworth, Traditional medicinal plants of Rarotonga, Cook Islands Part I, Int. J. Crude Drug Res. 28 (1990) 209-218.

[13] B.G. Mendes, M.J. Machado, M. Falkenberg, Triagem de glicolipids em plantas medicinais, Rev. Bras. Farmacogn. 16 (2006) 568-575.

[14] National Research Council (US) Committee. Guide for the Care and Use of Laboratory Animals, 8th Ed, The National Academies Press, Washington, DC, 2011.

[15] V. Ramamurthy, M. Sathiyadevi, Preliminary phytochemical screening of methanol extract of Indigofera trita Linn, J. Mol. Histol. Med. Physiol. 2 (2017) 122.

[16] Y. Vaghasiya, R. Dave, S. Chanda, Phytochemical analysis of some medicinal plants from Western region of India, Research Journal of Medicinal Plants. 5 (2011) 567-576.

[17] OECD, OECD Guidelines for Acute Toxicity of Chemicals. Organization for Economic Cooperation and Development, Paris, France, 2001, No. 420.

[18] P.A. Akah, A. Nwanbie, Evaluation of Nigerian traditional medicines plants used for rheumatic (inflammatory) disorder, J. Ethnopharmacol. 42 (1994) 179-182.

[19] A. Tjolsen et al., The formalin test: An evaluation of the method, Pain. 51 (1992) 5-17.

[20] C.S. Nworu et al., Extracts of Ficus exasperata leaf inhibit topical and systemic inflammation in rodents and suppress LPS-induced expression of mediators of inflammation in macrophages, Journal of Immunotoxicology. 10 (2013) 302-310.

[21] A. Bertolini, A. Ottani, M. Sandrini, Dual acting anti- inflammatory drugs: A reappraisal, Pharmacol. Res. 44 (2001) 437-450.

[22] S. Basu, B.E. Hazra, Evaluation of nitric oxide scavenging activity, in vitro and ex vivo, of selected medicinal plants traditionally used in inflammatory diseases, Phytother. Res. 20 (2006) 896-900.

[23] The Wealth of India, Raw Material. 11 (1988) 5.

[24] A.V.S.S. Sammbamurthy, Dictionary of medicinal plants, CBS Publishers \& Distributors, 2006.

[25] K.R. Kirtikar, B.D. Basu, Indian medicinal plant text. 2 (2006) 892-894.

[26] J.K.L. Campos et al., Anti-inflammatory and antinociceptive activities of Bauhinia monandra leaf lecithin, Biochimie Open. (2016) 62-68.

[27] S.B. Dhull, P. Kaur, S.S. Purewal, Phytochemical analysis, phenolic compounds, condensed tannin content and antioxidant potential in Marwa (Origanum majorana) seed extracts, Resource Efficient Technologies. 2 (2016) 168-174.

[28] P. Kaur et al., Tulsi (Ocimum tenuiflorum) seeds: in vitro DNA damage protection, bioactive compounds and antioxidant potential, Journal of Food Measurement and Characterization. 12 (2018) 1530-1538.

[29] H.L. Yu et al., Anti-inflammatory and antinociceptive effects of 6-(4-chlorophenoxy)terazolo[5,1-a]phthalazine in mice, Pharmacol. Rep. 64 (2012) 1155-1165.

[30] A.L.A.P. Gil et al., Anti-inflammatory and antinociceptive activities of the ethanolic extract of Boougainvilla xbuttiana, J. Ethnopharmacol. 144 (2012) 712-719.

[31] H.S. Kang, J.Y. Lee, C.J. Kim, Anti-inflammatory activity of arctigenin from Forsythiae fructus, J. Ethnopharmacol. 166 (2008) 305-310.

[32] S. Solomon, N. Muruganathan, M.M. Senthamilselvi, Anti-oxidant and Anti-inflammatory activity of Bauhinia tomentosa (Flowers), Indo Am. J. Pharm. Res. 6 (2016) 4321-4326.

[33] D.L. Ajaghaku et al., Mechanism of anti-inflammatory activity of the leaf extract and fractions of Milletia aboensis, Int. Res. J. Pharm. 4 (2013) 54-59.

[34] E.E. Hisam et al., Antiulcer Activity of the chloroform extract of Bauhinia purpurea leaf, Pharm. Biol. 50 (2012) 1498-1507. 
[35] N. Kannan, K.M. Sakthivel, C. Guruvayoorappan, Nephroprotective effect of Bauhinia tomentosa Linn against cisplatin-induced renal damage, J Environ. Pathol. Toxicol. Oncol. 35 (2016) 99-107.

[36] I.B. Calou et al., Topically applied diterpenoids from Egletes viscosa (Asteraceae) attenuate dermal inflammation in mouse ear induced by tetradecanoylphorbol-13-acetate and oxazolone, Biol. Pharm. Bull. 31 (2008) 1511-1516.

[37] D.O. Salinas-Sánchez et al., A. Anti-inflammatory activity of hautriwaic acid isolated from Dodonaea viscosa leaves, Molecules. 17 (2012) 4292-4299.

[38] A. Chakraborty, A.H. Brantner, Study of alkaloids from Adhatoda vasica Nees on their antiinflammatory activity, Phytother. Res. 15 (2001) 532-534.

[39] Y.C. Chen et al., Inhibition of nitric oxide synthase inhibitors and lipopolysaccharide induced inducible NOS and cyclooxygenase- 2 gene expressions by rutin, quercetin, and quercetin pentaacetate in RAW 264.7 macrophages, J. Cell. Biochem. 82 (2001) 537-548.

[40] S. Kumar, V. Kumar, O.M. Prakash, Pharmacognostic study and anti-inflammatory activity of Callistemon lanceolatus leaf, Asian Pac. J. Trop. Biomed. 1 (2011) 177-181. 